九州大学学術情報リポジトリ

Kyushu University Institutional Repository

\title{
Linkage Studies in Rice (Oryza sativa L.) : On Some Virescent and Chlorina Mutants
}

Omura, Takeshi

Laboratory of Plant Breeding, Faculty of Agriculture, Kyushu University

\section{Iwata, Nobuo}

Laboratory of Plant Breeding, Faculty of Agriculture, Kyushu University

Satoh, Hikaru

Laboratory of Plant Breeding, Faculty of Agriculture, Kyushu University

https://doi.org/10.5109/23681

出版情報 : 九州大学大学院農学研究院紀要. 23 (1/2)，pp.85-93，1978-10. Kyushu University バージョン：

権利関係 : 


\title{
Linkage Studies in Rice (Oryza sativa L.) On Some Virescent and Chlorina Mutants
}

\author{
Takeshi Omura, Nobuo Iwata and Hikaru Satoh \\ Laboratory of Plant Breeding, Faculty of Agriculture, \\ Kyushu University 46-01, Fukuoka 812 \\ (Received August 2, 1978)
}

\begin{abstract}
Linkage analyses on five virescent and four chlorina mutants were carried out. Six of these mutants, $v_{1}, v_{2}, v_{5}, c h_{1}, c h_{2}$ and $c h_{3}$, were found to belong to the eleventh linkage group. Also. it was found that $v_{3}$ and $\mathrm{ch}$, belonged to the first linkage group, and $\boldsymbol{v}_{4}$ to the eighth group. The sequences of the genes in respective linkage groups were made clear, though a few of the loci were undetermined.
\end{abstract}

\section{INTRODUCTION}

Various kinds of chlorophyll mutants are known in rice, however, only a few of the linkage studies on the mutants had been made (Jodon, 1940; Nagao and Takahashi, 1960; Nagamatsu and Omura, 1962) before the authors reported some of them (Iwata and Omura, 1971, 1975, 1978). Most of the chlorophyll mutants are modified their character manifestation by environmental conditions, being clearly distinguishable from the normal in certain conditions but indistinguishable in other conditions. Therefore, the mutants are usable in linkage analysis, when the conditions suitable to character manifestation of the mutants are known.

Recently, many chlorophyll mutants have been obtained, then the authors are carrying on the studies on their character manifestation as shown in some papers (Omura and Tanaka, 1959; Omura et al., 1977; Satoh et al., 1977) on the one hand, and their linkage analyses on the other hand. The present paper described the results of linkage analyses on some of the virescent and chlorina mutants.

\section{MATERIALS AND METHODS}

The materials used were five virescent seedlings, $v_{1}, v_{2}, v_{3}, v_{4}$ and $v_{5}$, and four chlorina, $c h_{1}, c h_{2}, c h_{3}$ and $c h_{4}$.

The virescent mutants sprout out white leaves under low temperature condition, but pale green or nearly normal green leaves under high temperature condition, though the mutants have different threshold temperature for chlorophyll accumulation. Contrary, the chlorina mutants sprout out yellowish green leaves, their typical characteristics, under high temperature condition. Their main characteristics and sources are as follows. 
$v_{1}$ : The threshold temperature is $22^{\circ} \mathrm{C}$ (Omura et al., 1977). When it is sown in late May, ordinary sowing time in Fukuoka, young seedlings are almost whole white but leaves emerging at or after transplanting are pale green with white midrib. Emerging panicles are white in color. It was introduced from Dr. Jodon of U. S. Department of Agriculture.

$\mathrm{v}$,: The threshold temperature is about $20^{\circ} \mathrm{C}$. Differing from $v_{1}$, midrib and panicles are not white but green. Other characteristics are almost the same as $v_{1}$. A spontaneous mutant from a Japanese cultivar "Yaeho".

$v_{3}$ : The threshold temperature is about $30^{\circ} \mathrm{C}$. An induced mutant from a Japanese cultivar "Kinmaze" by $N$-nitroso- $N$-methylurea treatment.

$v_{4}$ : The threshold temperature is not examined. It is an induced mutant from "Norin 8" by irradiation and introduced from Division of Genetics, National Institute of Agricultural Science (LT 3).

$\mathrm{v}$, : Except the threshold temperature is probably higher than $v_{3}$, it resembles $v_{3}$ in other characteristics. An induced mutant from "Kinmaze" as same as $v_{3}$.

ch,: When it is sown in late May, the distinction from the normal seedling is rather difficult, but after transplanting the chlorina chatacter of yellowish green leaves is clearly manifested. A spontaneous mutant stocked in our laboratory (HO 718-721).

$c h_{2}$ : Leaves of young seedling exhibit orange in color but leaves emerging thereafter are yellowish pale green and finally green (LT 4). The same source as $v_{4}$.

$c h_{3}$ : It manifested yellowish pale green leaves at just before heading. A spontaneous mutant stocked in our laboratory (HO 717).

$c h_{4}: I t$ is characterized by yellowish green leaves at tillering stage and by fewer culm and somewhat lower viability than the normal. It was induced in gamma field and introduced from Institute of Radiation Breeding, National Institute of Agricultural Science (No. 646).

Linkage was detected in $\mathrm{F}_{2}$ by the trisomic and conventional methods. Trisomics used were some types described by Iwata and Omura (1975). Marker genes used in conventional method are listed in Table 1. Recombination

Table 1. List of marker genes used and their linkage groups.

\begin{tabular}{|c|c|c|c|}
\hline Linkage group & Gene symbol & Character & Reference \\
\hline I & $\begin{array}{l}w x \\
d p_{1} \\
C \\
w s \\
C l\end{array}$ & $\begin{array}{l}\text { waxy endosperm } \\
\text { depressed palea } 1 \\
\text { chromogen for anthocyanin } \\
\text { white striped leaf } \\
\text { clustered spikelets }\end{array}$ & $\begin{array}{c}\text { Nagamatsu and Omura (1962) } \\
\text { "' } \\
\text { Nagao and Takahashi (1963) }\end{array}$ \\
\hline VIII & $\begin{array}{l}\text { la } \\
s p\end{array}$ & $\begin{array}{l}\text { lazy } \\
\text { short panicle }\end{array}$ & Iwata and Omura (1971) \\
\hline XI & $\begin{array}{l}c h_{1} \\
f c \\
b c_{1} \\
d l\end{array}$ & $\begin{array}{l}\text { chlorina } 1 \\
\text { fine culm, tillering } \\
\text { brittle culm } 1 \\
\text { drooping leaf }\end{array}$ & $\begin{array}{l}\text { Iwata and Omura (1977) } \\
\text { Iwata and Omura (1971) }\end{array}$ \\
\hline
\end{tabular}


values were calculated in $\mathrm{F}_{2}$ and $\mathrm{F}_{3}$ by the method of maximum likelihood. The $F_{2}$ segregation for $c h_{4}$ was disturbed by differential viability. It is known, however, that the differential viability does not influence the estimation of recombination value but influence the expected numbers of four phenotypes (Bailey, 1961). Therefore, the expected number was calculated in consideration of the parameter of differential viability $(u)$, which is defined for the relative excess of $c h_{4}^{+}$phenotypes over $c h_{4}$. The value of $u$ is estimated from numbers of four phenotypes, $a, b, c$ and $\mathrm{d}$, by the following equation,

$$
u=(a+b) / 3(c+d) \text {. }
$$

Table 2. Linkage relations between four genes belonging to the eleventh linkage group.

\begin{tabular}{|c|c|c|c|c|c|c|c|c|c|}
\hline \multirow{7}{*}{$\begin{array}{l}\text { Gene pair } \\
c h_{1}-f c\end{array}$} & \multicolumn{2}{|l|}{ Items } & \multicolumn{5}{|c|}{ Segregation mode } & \multirow{2}{*}{$\begin{array}{l}\text { Recombination } \\
\text { value }(\%)\end{array}$} & \multirow{2}{*}{$\chi_{[3]}^{2}$} \\
\hline & \multicolumn{2}{|c|}{ Phase $\begin{array}{l}\text { No. } \\
\text { cross }\end{array}$ of } & \multirow{2}{*}{$\begin{array}{c}++ \\
461 \\
(469.9)\end{array}$} & \multirow{2}{*}{ 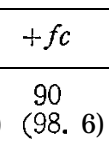 } & \multirow{2}{*}{$\begin{array}{l}\text { ch, }+ \\
111 \\
(98.6)\end{array}$} & $c h_{1} f c$ & Total & & \\
\hline & Coup. & 4 & & & & $\stackrel{96}{(90,9)}$ & 758 & $30.8 \pm 2.1$ & 2.763 \\
\hline & Rep. & 6 & $\begin{array}{l}587 \\
(556.3)\end{array}$ & $\begin{array}{l}246 \\
(253.0)\end{array}$ & $\begin{array}{l}232 \\
(253.0)\end{array}$ & $(16$. & 1,079 & $24.9 \mathrm{a} 2.8$ & 4.087 \\
\hline & $F_{3}$ from $F_{2}$ & lants & Seg & & Non-seg. & & Total & & \\
\hline & $\begin{array}{l}\left(c h_{1}^{+} f c\right. \\
\left(c h_{1} f c^{+}\right.\end{array}$ & & $\begin{array}{l}37 \\
36\end{array}$ & & $\begin{array}{l}47 \\
47\end{array}$ & & $\begin{array}{l}84 \\
83\end{array}$ & $\begin{array}{l}28.2 \pm 4.5 \\
27.7 \pm 4.4\end{array}$ & \\
\hline & Weighted & nean & & & & & & $28.5 \pm 1.5$ & \\
\hline & Phase $\begin{array}{r}\mathrm{N} \\
\mathrm{cr}\end{array}$ & $\begin{array}{l}\text { of } \\
\text { s s }\end{array}$ & $\mathrm{AB}$ & $\mathrm{Ab}$ & $\mathrm{aB}$ & $\begin{array}{l}a b \\
36\end{array}$ & Total & & \\
\hline$c h,-b c$ & $F_{2}$ Coup. & 2 & $\begin{array}{c}413 \\
(404.1)\end{array}$ & $\begin{array}{c}135 \\
(144.2)\end{array}$ & $\begin{array}{l}147 \\
(144.2)\end{array}$ & $\left.{ }_{46}^{6}\right)^{6}$ & 731 & 54. If 2.9 & 1.008 \\
\hline & Rep. & 3 & $\begin{array}{l}419 \\
(425.5)\end{array}$ & $\begin{array}{l}131 \\
(146.8)\end{array}$ & $\begin{array}{l}167 \\
(146.8)\end{array}$ & $(44$. & 763 & $48.0 \pm 2.8$ & 4.675 \\
\hline & Weighted & nean & & & & & & $50.9 \pm 2.0$ & \\
\hline$c h_{1}-d l$ & $\mathrm{~F}_{2}$ Rep. & 4 & $\begin{array}{l}628 \\
(629.5)\end{array}$ & $\begin{array}{l}204 \\
(215.0)\end{array}$ & $\begin{array}{l}227 \\
(215.0) \\
-27\end{array}$ & 56 & 1,126 & $48.6 \pm 2.3$ & 1.240 \\
\hline fc- bc, & $\mathrm{F}_{\mathbf{2}}$ Coup. & 1 & $\begin{array}{l}119 \\
(109.7)\end{array}$ & $(26.8)$ & (26. 8) & $\begin{array}{l}(18.7) \\
36\end{array}$ & 182 & $35.8 \pm 4.6$ & 2.829 \\
\hline & Rep. & 7 & $\begin{array}{l}751 \\
(702.0)\end{array}$ & $\begin{array}{l}258 \\
(282.7)\end{array}$ & $\begin{array}{l}268 \\
(282.7)\end{array}$ & $(45$. & 1,313 & $37.2 \pm 2.3$ & 8.339 \\
\hline & Weighted & nean & & & & & & $37.0 \mathrm{f} 2.1$ & \\
\hline $\mathrm{fc}-d l$ & $\mathrm{~F}_{2}$ Rep. & 9 & $\begin{array}{l}1,014 \\
(970.4)\end{array}$ & $\begin{array}{l}324 \\
(346.6)\end{array}$ & $\begin{array}{l}338 \\
(346.6)\end{array}$ & (92. & 1,756 & $45.9 \pm 1.9$ & 5.309 \\
\hline$b c_{1}-d l$ & $\mathrm{~F}_{2}$ Coup. & 18 & $\begin{array}{l}2,335 \\
(2,283.0)\end{array}$ & $\begin{array}{l}641 \\
(648.8)\end{array}$ & $\begin{array}{c}627 \\
(648.8)\end{array}$ & $\begin{array}{l}306 \\
(228.5)\end{array}$ & 3,909 & $42.0 \pm 1.1$ & 3.547 \\
\hline & Rep. & 4 & $\begin{array}{c}647 \\
(616.1)\end{array}$ & $\begin{array}{l}204 \\
(207.4)\end{array}$ & $\begin{array}{l}190 \\
(207.4)\end{array}$ & $(67$. & 1,098 & $49.4 \pm 2.3$ & 4.586 \\
\hline & Weighted & nean & & & & & & $43.4 \pm 1.0$ & \\
\hline
\end{tabular}




\section{RESULTS AND DISCUSSION}

As it was found that ch, belonged to the eleventh linkage group by the translocation method (Iwata and Omura, 1971), it was used as one of the marker genes of this group. The interrelation of the marker genes are shown in Table 2. The sequence of $c h_{1}-f c-b c_{1}-d l$ is suggested from respective recombination values, though that of $b c_{1}-d l-c h_{1}$ was previously reported (Iwata and Omura, 1971). The recombination values of $v_{1}-f c$ and $v_{1}-b c_{1}$ were both $17.9 \%$ (Table 3), and that of fc-bc, was $37.0 \%$ (Table 2). Consequent-

Table 3. Linkage relations between $v_{1}$ and genes belonging to the eleventh linkage group.

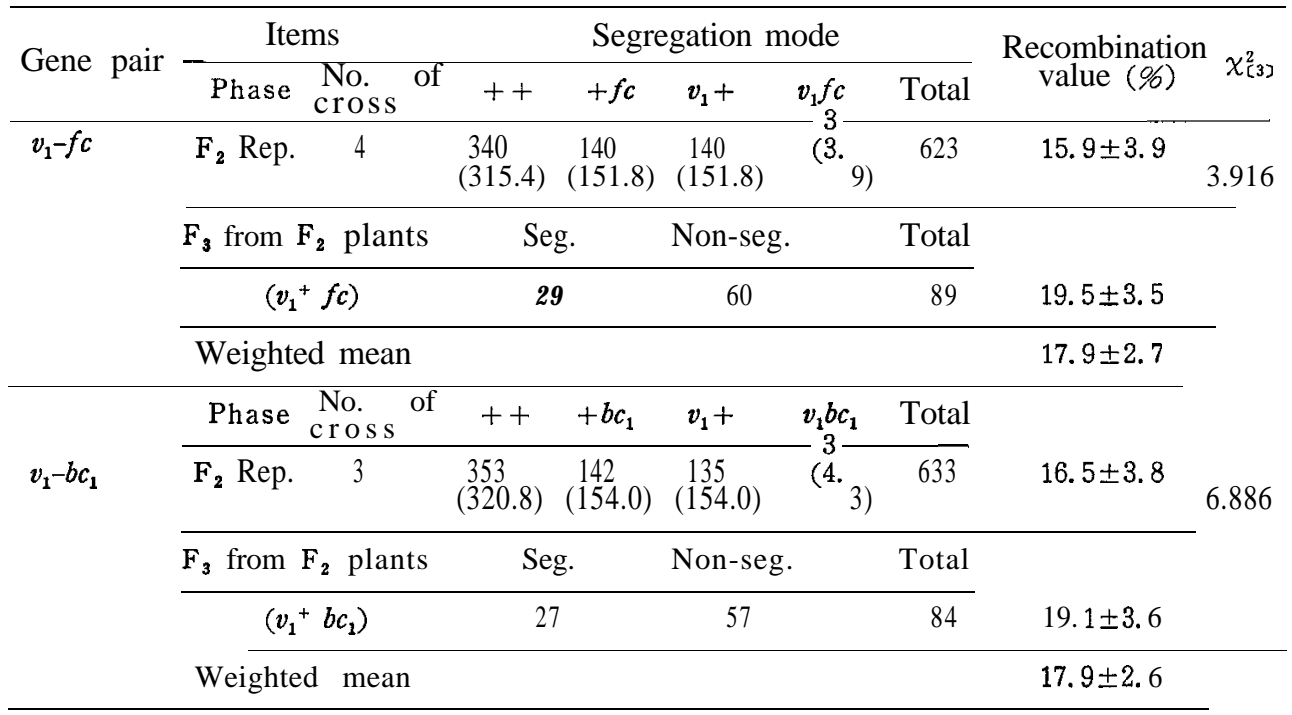

Table 4. Linkage relations between $\boldsymbol{v}_{\mathbf{2}}$ and genes belonging to the eleventh linkage group.

\begin{tabular}{|c|c|c|c|c|c|c|c|c|c|}
\hline \multirow{2}{*}{ Gene pair } & \multirow{2}{*}{ Phase } & \multirow{2}{*}{$\begin{array}{l}\text { No. of } \\
\text { cross }\end{array}$} & \multicolumn{5}{|c|}{ Segregation mode in $\mathrm{F}_{2}$} & \multirow{2}{*}{$\begin{array}{l}\text { Recombination } \\
\text { value (\%) }\end{array}$} & \multirow{2}{*}{$x_{(3)}^{2}$} \\
\hline & & & $\mathrm{AB}$ & $\mathrm{Ab}$ & $\mathrm{aB}$ & $\mathrm{ab}$ & Total & & \\
\hline \multirow[t]{3}{*}{$v_{2}-b c_{1}$} & coup. & 15 & $\begin{array}{c}1,952 \\
(1,910.0)\end{array}$ & $\begin{array}{l}396 \\
(397.7)\end{array}$ & $\begin{array}{l}382 \\
(397.7)\end{array}$ & $\begin{array}{l}347 \\
(371.5)\end{array}$ & 3,077 & $30.5 \pm 1.0$ & 3.171 \\
\hline & Rep. & 3 & $\begin{array}{l}388 \\
(359.6)\end{array}$ & $\begin{array}{l}151 \\
(169.9)\end{array}$ & $\begin{array}{l}162 \\
(169.9)\end{array}$ & (6. & 706 & $19.3 \pm 3.6$ & 5.103 \\
\hline & Weighted & mean & & & & & & $29.7 \pm 1.0$ & \\
\hline \multirow[t]{3}{*}{$v_{2}-d l$} & coup. & 11 & $\begin{array}{c}1,411 \\
(1,388.5)\end{array}$ & $\begin{array}{l}244 \\
(245.0)\end{array}$ & $\begin{array}{l}238 \\
(245.0)\end{array}$ & $\begin{array}{l}285 \\
(? 00.5)\end{array}$ & 2,178 & $25.8 \pm 1.1$ & 1.271 \\
\hline & Rep. & 9 & $\begin{array}{c}1,142 \\
(1,118.9)\end{array}$ & $\begin{array}{l}474 \\
(501.9)\end{array}$ & $\begin{array}{l}509 \\
(501.9)\end{array}$ & $(38$. & 2,161 & $26.7 \pm 2.1$ & 2.274 \\
\hline & Weighted & mean & & & & & & $26.0 \pm 1.0$ & \\
\hline
\end{tabular}


Table 5. Linkage relation between $\boldsymbol{v}_{5}$ and $c h_{1}$ belonging to the eleventh linkage group.

\begin{tabular}{|c|c|c|c|c|c|c|}
\hline \multicolumn{2}{|l|}{ Items } & \multicolumn{4}{|c|}{ Segregation mode } & \multirow{2}{*}{$\begin{array}{c}\text { Recombination } \\
\text { value }(\%)\end{array}$} \\
\hline Phase $\quad \begin{array}{c}\text { No. of } \\
\text { cross }\end{array}$ & ++ & $+c h_{1}$ & $v_{5}+$ & $v_{5} c h_{1}$ & Total & \\
\hline $\mathrm{F}_{2}$ Rep. & 193 & 93 & 59 & 0 & 345 & $\doteqdot 0$ \\
\hline$F_{3}$ from $F_{2}$ plants & Seg. & & Non-seg. & & Total & \\
\hline $\begin{array}{l}\left(v_{5}^{+} c h_{1}\right) \\
\left(v_{5} c h_{1}^{+}\right)\end{array}$ & $\begin{array}{l}3 \\
2\end{array}$ & & $\begin{array}{l}83 \\
35 \\
\end{array}$ & & $\begin{array}{l}86 \\
37\end{array}$ & $\begin{array}{l}1.8 \pm 1.0 \\
2.8 \pm 2.0\end{array}$ \\
\hline Weighted mean & & & & & & $2.0 \pm 0.9$ \\
\hline
\end{tabular}

Table 6. Linkage relations between two genes, $\mathbf{c h}$, and $\mathbf{c h}$,, newly described and marker genes belonging to the eleventh linkage group.

\begin{tabular}{|c|c|c|c|c|c|c|c|c|c|}
\hline \multirow{2}{*}{ Gene pair } & \multirow{2}{*}{ Phase } & \multirow{2}{*}{$\begin{array}{l}\mathrm{No} \\
\text { cross }\end{array}$} & \multicolumn{5}{|c|}{ Segregation mode in $\mathbf{F}_{\mathbf{2}}$} & \multirow{2}{*}{$\begin{array}{c}\text { Recombination } \\
\text { value }(\%)\end{array}$} & \multirow{2}{*}{$\chi_{[3]}^{2}$} \\
\hline & & & $\mathrm{AB}$ & $\mathrm{Ab}$ & $\mathrm{aB}$ & $a b$ & Total & & \\
\hline$c h_{2}-b c_{1}$ & Rep. & 2 & $\begin{array}{l}212 \\
(201.6)\end{array}$ & $\begin{array}{c}92 \\
(84.9)\end{array}$ & $\begin{array}{c}69 \\
(84.9)\end{array}$ & $\begin{array}{c}9 \\
(10.6)\end{array}$ & 382 & $33.4 \mathrm{t} 4.5$ & 4.350 \\
\hline$c h_{2}-v_{2}$ & Rep. & 2 & 175 & 106 & 101 & $1 \hat{2}$ & 382 & $\doteqdot 0$ & \\
\hline$c h_{2}-d l$ & Rep. & 3 & $\begin{array}{l}303 \\
(305.7)\end{array}$ & $\begin{array}{c}139 \\
(125.3) \\
93.3)\end{array}$ & $\begin{array}{l}134 \\
(135.3)\end{array}$ & $\begin{array}{c}(11.7) \\
3\end{array}$ & 588 & $28.2 \pm 3.7$ & 0.145 \\
\hline$c h_{3}-c h_{1}$ & Rep. & 2 & $\begin{array}{c}181 \\
(178.6)\end{array}$ & (84. 6 ) & $\begin{array}{r}(84 . \\
-39\end{array}$ & $(3$. & 351 & 18. $9 \pm 5.1$ & 2.199 \\
\hline \multirow[t]{3}{*}{$c h_{3}-f c$} & coup. & 2 & $\begin{array}{l}220 \\
(227.4)\end{array}$ & $(35.8)$ & $(35.8)$ & $(51.9)$ & 351 & $23.1 \pm 2.6$ & 1.039 \\
\hline & Rep. & 2 & $\begin{array}{l}193 \\
(188.2)\end{array}$ & $\begin{array}{l}93 \\
(90.8)\end{array}$ & $\begin{array}{l}84 \\
(90.8)\end{array}$ & $\stackrel{2}{(2.2)}$ & 372 & $15.2 \pm 4.9$ & 0.703 \\
\hline & \multicolumn{6}{|c|}{ Weighted mean } & \multicolumn{3}{|c|}{$21.3 \pm 2.3$} \\
\hline
\end{tabular}

ly, it is concluded that $v_{1}$ is located between fc and bc,. Jodon (1940) found that a virescent gene $(v)$ linked with gu ( $\mathrm{wx}$ in our symbol), as (C) and $\mathrm{Cl}$. This fact indicates that $\mathrm{v}$ belongs to the first linkage group, however, Takahashi and Morimura (1968) could not find the linkage relations, using a virescent gene introduced from Dr. Jodon. It is uncertain whether $v_{1}$ is identical with $\mathrm{v}$ or not, though $v_{1}$ is also introduced from Dr. Jodon.

Two virescent genes, $v_{2}$ and $v_{5}$, were found to belong to this group. The recombination values of $v_{2}-b c_{1}$ and $v_{2}-d l$ were 29.7 and $26.0 \%$, respectively (Table 4). Then, the sequence of $b c_{1}-v_{2}-d l$ is reliable. The recombination value of $v_{5}-c h_{1}$ was calculated in $F_{3}$ from two kinds of singly dominant $F_{2}$ at $2.0 \%$ (Table 5). This value shows that $v_{5}$ is located near by $c h_{1}$.

Two chlorina genes, ch, and $c$, , belonged also to this group. The recombination values of $c h_{2}-b c_{1}$ and $c h_{2}-d l$ were estimated at 33.4 and $28.2 \%$, respectively (Table 6). The recombination value of $43.4 \%$ have already been obtained between $b c_{1}$ and $d l$ (Table 2). From these results, the sequence of $b c_{1}-c h_{2}-d l$ was confirmed. 


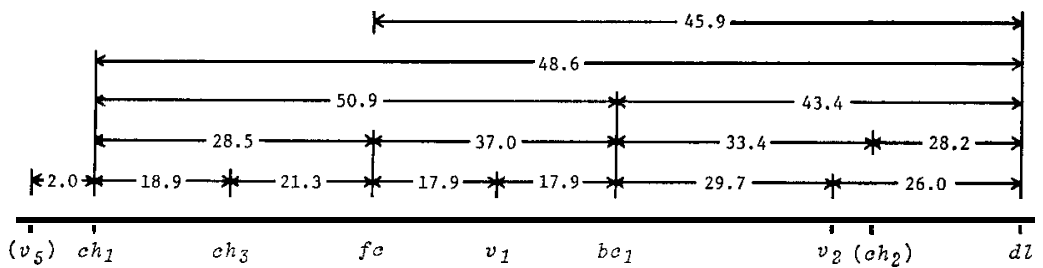

Fig. 1. Sequence of the nine genes at the eleventh linkage group.

Table 7. Linkage relations between $v_{3}$ and genes belonging to the first linkage group.

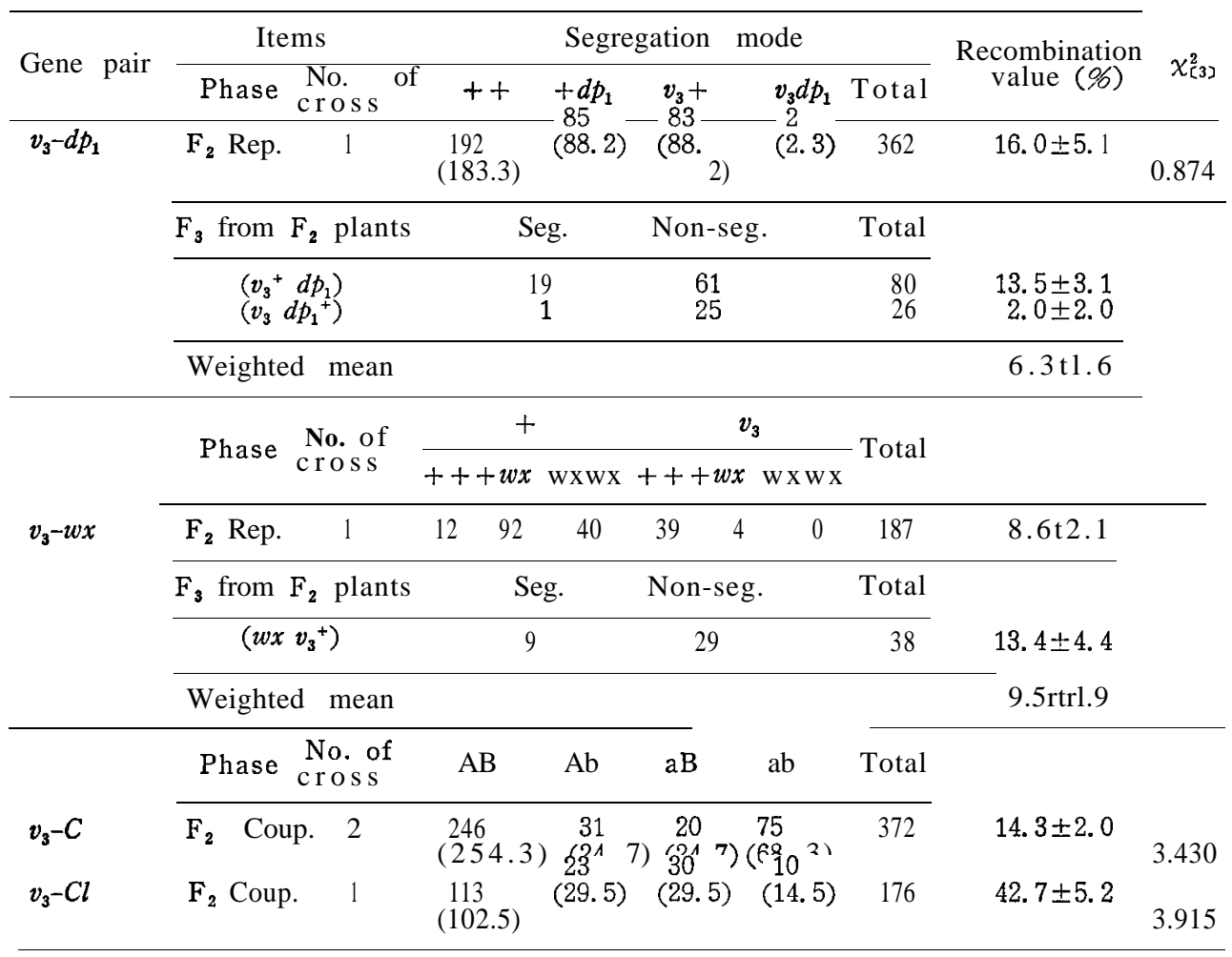

The close linkage relation was observed between $c h_{2}$ and $v_{2}$, however, the recombination value was not calculated, because none of the doubly recessive plant was segregated in $F_{2}$ in repulsion phase (Table 6). As mentioned above, $v_{2}$ was also located between $b c$, and $d l$, therefore, the loci of $c h$, and $v_{2}$ should be adjacent each other, although accurate distance of them is so far uncertain. The recombination values of 18.9 and $21.3 \%$ were calculated in $c h_{3}-c h_{1}$ and $c h_{3}-f c$, respectively (Table 6). As the value of $c h_{1}-f c$ was 28.5 $\%$ (Table 2), ch, is located between $c h_{1}$ and fc. Based on these results, the sequence of the nine genes at the eleventh linkage group is tentatively drawn 
as shown in Fig. 1.

The other virescent gene $\left(v_{3}\right)$ linked with marker genes of the first linkage group (Table 7). The recombination values between $\boldsymbol{v}_{3}$ and wx, $d p_{1}, C$ and

Table 8. Trisomic segregation of $c h_{\mathbf{4}}$ in $F_{\mathbf{2}}$ of a cross with $\mathrm{B}$ type of trisomics.

\begin{tabular}{|c|c|c|c|c|c|c|}
\hline \multirow{3}{*}{$\begin{array}{l}\text { Portion of } \\
\text { population }\end{array}$} & \multicolumn{3}{|c|}{ Observed number } & \multicolumn{3}{|c|}{$x^{2}$} \\
\hline & \multirow[b]{2}{*}{ Dominant } & \multirow[b]{2}{*}{ Recessive } & \multirow[b]{2}{*}{ Total } & \multirow{2}{*}{$\begin{array}{c}\text { Disomic } \\
3: 1\end{array}$} & \multicolumn{2}{|c|}{ Trisomic } \\
\hline & & & & & $\begin{array}{c}8: 1 \\
\text { for } 2 x\end{array}$ & $\begin{array}{c}44: 1 \\
\text { for } 2 x+1\end{array}$ \\
\hline $\begin{array}{l}2 \mathrm{x} \\
2 \mathrm{x}+1 \\
\text { Total }\end{array}$ & $\begin{array}{r}139 \\
83 \\
222\end{array}$ & $\frac{1}{15}$ & $\begin{array}{r}84 \\
237\end{array}$ & 44. 063 & 0.596 & 0.412 \\
\hline
\end{tabular}

*** Significant at $0.1 \%$ level.

Table 9. Linkage relations between $\boldsymbol{c h}_{\boldsymbol{A}}$ and genes belonging to the first linkage group.

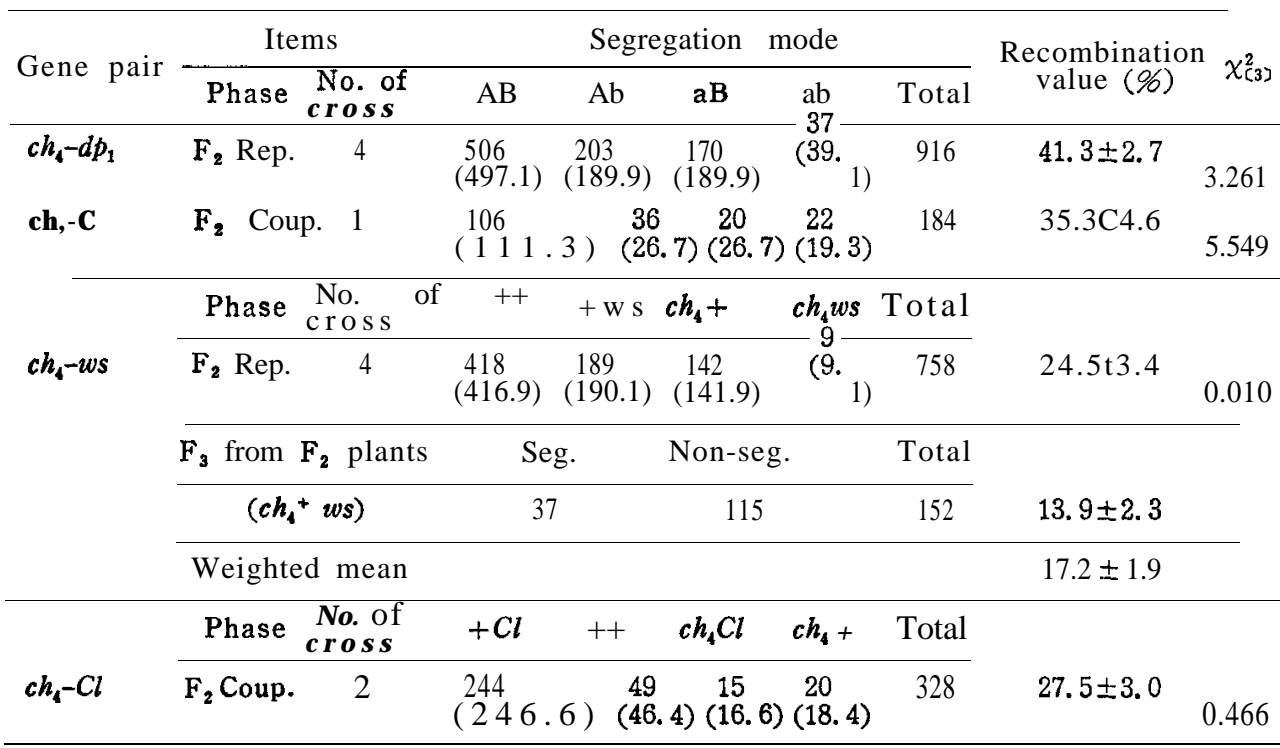

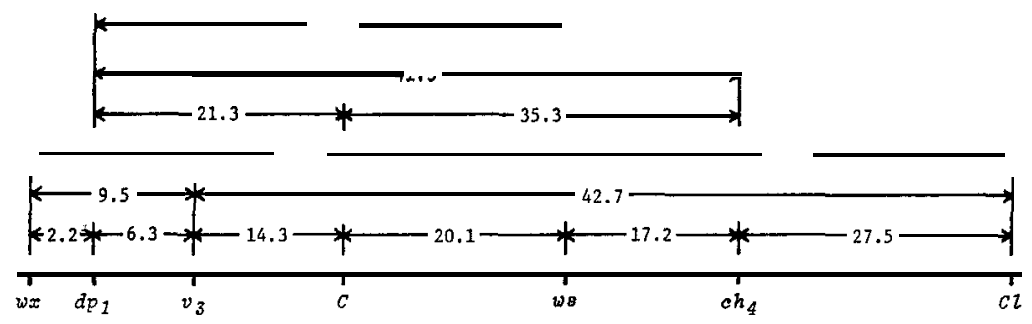

Fig. 2. Sequence of the seven genes at the first linkage group. 
Table 10. Trisomic and disomic segregations of $\boldsymbol{v}_{4}$ in $\mathrm{F}_{2}$ of a cross with $\mathrm{G}$ type of trisomics.

\begin{tabular}{|c|c|c|c|c|c|c|}
\hline \multirow{2}{*}{$F_{1}$ plants } & \multicolumn{3}{|c|}{ Observed number } & \multirow{2}{*}{$\begin{array}{c}\chi^{2} \text { for } \\
3: 1\end{array}$} & \multicolumn{2}{|c|}{ Ratio of domi.: rece. } \\
\hline & Dominant & Recessive & Total & & Theoretical & Observed \\
\hline Trisomic & 183 & 6 & 189 & 48. $016 * * *$ & $8: 1-44: 1$ & $30.5: 1$ \\
\hline Disomic & 367 & 129 & 496 & 0.269 & $3: 1$ & \\
\hline
\end{tabular}

*** Significant at $0.1 \%$ level.

Table 11. Linkage relations between $v_{4}$ and genes belonging to the eighth linkage group, and between la and $s p$.

\begin{tabular}{|c|c|c|c|c|c|c|c|c|c|}
\hline \multirow{2}{*}{ Gene pair } & \multicolumn{3}{|c|}{ Items } & \multicolumn{4}{|c|}{ Segregation mode } & \multirow{2}{*}{$\begin{array}{c}\text { Recombination } \\
\text { value }(\%)\end{array}$} & \multirow{2}{*}{$x_{[3]}^{2}$} \\
\hline & Phase & $\begin{array}{l}\text { No } \\
\text { cross }\end{array}$ & of ++ & $\begin{array}{l}+l a \\
-33-\end{array}$ & $\begin{array}{c}v_{4}+ \\
-21\end{array}$ & $\begin{array}{c}v_{4} l a \\
-96\end{array}$ & Total & & \\
\hline \multirow[t]{6}{*}{$\mathrm{v},-\mathrm{la}$} & $\mathrm{F}_{2}$ Coup. & 3 & $\begin{array}{l}343 \\
(342.7)\end{array}$ & $(27$. & $(27$. & $(96$. & 493 & 11. $6 \pm 1.6$ & 0.024 \\
\hline & Rep. & 2 & $\begin{array}{l}215 \\
(224.2)\end{array}$ & $\begin{array}{l}118 \\
(108.1)\end{array}$ & $\begin{array}{l}107 \\
(108.1)\end{array}$ & $(2.7)$ & 443 & $15.5 \pm 4.6$ & 1.337 \\
\hline & $\mathbf{F}_{3}$ from $F_{2}$ & 2 plant & Seg. & & Non-seg & & Total & & \\
\hline & $\begin{array}{l}\left(v_{4}^{+} l a\right. \\
\left(v_{4} l a^{+}\right.\end{array}$ & & $\begin{array}{l}14 \\
14\end{array}$ & & $\begin{array}{l}75 \\
64\end{array}$ & & $\begin{array}{l}89 \\
78\end{array}$ & $\begin{array}{l}8.5 \mathrm{f} 2.3 \\
9.9 \pm 2.6\end{array}$ & \\
\hline & Weighted & mean & & & & & & $10.8 \pm 1.1$ & \\
\hline & Phase $\mathrm{N}$ & $\begin{array}{l}\text { No. of } \\
\text { cross }\end{array}$ & $\mathrm{AB}$ & $\mathrm{Ab}$ & $\mathrm{aB}$ & $a b$ & Total & & \\
\hline$v_{4}-s p$ & $\mathrm{~F}_{2} \quad$ Rep. & 1 & $\begin{array}{l}54 \\
(63.4)\end{array}$ & $\begin{array}{c}37 \\
(29.6)\end{array}$ & $\begin{array}{l}31 \\
(29.6)\end{array}$ & $\begin{array}{l}2 \\
(1.4)\end{array}$ & 124 & $21.1 \pm 8.5$ & 3.569 \\
\hline \multirow[t]{3}{*}{$l a-s p$} & $F_{2}$ Coup. & 24 & $\begin{array}{c}2,831 \\
(2,884.5)\end{array}$ & $\begin{array}{l}455 \\
(443.3)\end{array}$ & $\begin{array}{l}448 \\
(443.3)\end{array}$ & $\begin{array}{c}703 \\
(6-65.0)\end{array}$ & 4,437 & $22.5 \pm 0.7$ & 4.723 \\
\hline & Rep. & 7 & $\begin{array}{l}669 \\
(642.5)\end{array}$ & $\begin{array}{l}266 \\
(285.3)\end{array}$ & $\begin{array}{l}281 \\
(285.3)\end{array}$ & $(24$. & 1,237 & $27.8 \pm 2.6$ & 2.831 \\
\hline & Weighted & mean & & & & & & $22.9 \pm 0.7$ & \\
\hline
\end{tabular}

$\mathrm{Cl}$ were $9.5,6.3,14.3$ and $42.7 \%$, respectively, so the gene sequence was thought to be $w x-d p_{1}-v_{3}-C-C l$. It was confirmed that $c h_{4}$ belonged to the first linkage group by means of the trisomic segregation in $F_{2}$ of a cross with B type of trisomics (Table 8). The recombination values between $c h_{4}$ and $d p_{1}$, $\mathrm{C}$ and ws were calculated at 41.3, 35.3, 17.2 and $27.5 \%$, respectively (Table 9). Combining these values and the value of $30.6 \%$ between ws and Cl reported by Iwata and Omura (1971), it is concluded that $c h_{4}$ is located between ws and $\mathrm{Cl}$. Therefore, the sequence of these genes at the first linkage group is as shown in Fig. 2.

Takahashi and Morimura (1968) reported the linkage between a chlorina gene (chl) and $C, \mathrm{Cl}$ and wx with the recombination values of 33.0, 39.5 and $34.5 \%$, respectively. This chlorina gene (chl) sent by us is identical with ch,. As above mentioned, $c h_{1}$ belongs to the eleventh linkage group and 
never links with marker genes of the first linkage group.

Lastly, $v_{4}$ was found to belong to the eighth linkage group, showing the trisomic segregation in $F_{2}$ of a cross with $G$ type of trisomics (Table 10). The recombination values of $v_{4}-l a, v_{4}-s p$ and la-sp were 10.8, 21.1 and 22.9 $\%$, respectively (Table 11 ). Therefore, their sequence is either $l a-v_{4}-s p$ or $v_{4}-l a-s p$. Linkage relations between $v_{4}$ and the other marker genes of this group are under examination.

\section{REFERENCES}

Bailey. N. T. J. 1961 Introduction to the Mathematical Theory of Genetic Linkage. Oxford Univ. Press, London (England)

Iwata, N. and T. Omura 1971 Linkage analysis by reciprocal translocation method in rice plants (Oryza sativa L.) II. Linkage groups corresponding to the chromosome 5, 6, 8, 9, 10 and 11. Sci. Bull. Fac.Agr., Kyushu Univ., 25: 137-153 (in Japanese with English summary)

Iwata, N. and T. Omura 1975 Studies on the trisomics in rice plants (Oryza sativa L.) III. Relation between trisomics and genetic linkage groups. Japan. J. Breed., 25: 363-368

Iwata, N. and T. Omura 1977 Linkage studies in rice (Oryza sativu L.). On some mutants derived from chronic gamma irradiation. J. Fuc. Agr., Kyushu Univ., 21: 117-127

Iwata, N. and T. Omura 1978 Linkage studies in rice (Oryza sativa L.). Some albino genes and their linkage relations between marker genes. Sci. Bull. Fac. Agr., Kyushu Univ., 33: 11-18 (in Japanese with English summary)

Jodon, N. E. 1940 Inheritance and linkage relationships of a chlorophyll mutation in rice. J. Amer. Sci. Agron., 32: 342-346

Nagamatsu, T. and T. Omura 1962 Linkage study of the genes belonging to the first chromosome in rice. Japan. J. Breed., 12: 231-236

Nagao. S. and M. Takahashi 1960 Genetical studies on rice plant, XXIV. Preliminary report of twelve linkage groups in Japanese rice. J. Fac.Agr., Hokkuido Univ.. 51: 289. 298

Nagao. S. and M. Takahashi 1963 Trial construction of twelve linkage groups in Japanese rice (Genetical studies on rice plant, XXVII). J. Fac. Agr.. Hokkuido Univ., 53: 72-130

Omura, T., H. Satoh, I. Aiga and N. Nagao 1977 Studies on the character manifestation in chlorophyll mutants of rice I. Virescent mutants sensitive to low temperature. $J$. Fac. Agr., Kyushu Univ., 21: 129-140

Omura, T. and S. Tanaka 1959 Amounts of chlorophyll and carotenoid in chlorophyll mutants, chlorina and xantha, of rice. Report Kyushu Brunch Crop Sci. Soc. Japan, 14: 2426 (in Japanese)

Satoh, H.. I. Aiga and T. Omura 1977 Studies on the character manifestation in chlorophyll mutants of rice II. Xantha mutant sensitive to low temperature. Sci. Bull. Fuc. Agr., Kyushu Univ., 31: 189-193 (in Japanese with English summary)

Takahashi. M. and K. Morimura 1968 Preliminary report on the inheritance of clustering habit of spikelets in rice plant (Genetical studies on rice plant, XXXIV). J.Fac.Agr., Hokkaido Univ., 56: 67-77 